\title{
Dampak Dana Alokasi Khusus (DAK) Pertanian dan Irigasi Terhadap Produksi Padi Sawah dan Ketahanan Pangan Kabupaten/Kota di Provinsi Jambi
}

\author{
Zainuddin \\ Dosen Program Studi Agribisnis Fakultas Pertanian Universitas Batanghari \\ Jl. Slamet Riyadi, broni Jambi. 36122. Telp. +6274160103 \\ e-mail : zainuddin.ubr11@gmail.com
}

\begin{abstract}
How important is the impact of the Special Allocation Fund (SAF) on agriculture and irrigation as a policy in food production and food security in the regions. This research was conducted with the objectives of: 1) formulating an economic model for lowland rice commodities related to SAF financing for agriculture and irrigation in Jambi Province; and 2) to analysis of the impact of agricultural and irrigation SAF financing on the area of irrigation, rice fields, and food security in Jambi Province. The simulation results show that the increase in special allocation funds (agriculture and irrigation) has a positive impact on increasing the area of irrigated rice fields, food production and regional food security. It is recommended that the effectiveness and impact of the DAK allocation be synergized with the allocation of fertilizer and seed subsidies in each district/city. The focus of the allocation of DAK funds is not only limited to maintenance and repair of irrigation networks, but is extended to develop smal scale irrigation models for potential rice fields (rainfed, lebak, tidal). The potential of available land types requires the suitability of site-specific technology packages for rice and other food crops. Likewise, the use of cheaper alternative inputs. Reorientation of programs funded by DAK agriculture/irrigation is needed to realize its effectiveness and impact on food production and food security in the regions.
\end{abstract}

Keywords: Allocation Funds, Irrigation, Food Security, Simultaneous Model, Paddy

\begin{abstract}
Abstrak. Betapa pentingnya dampak Dana Alokasi Khusus (DAK) terhadap pertanian dan irigasi sebagai suatu kebijakan dalam produksi pangan dan ketahanan pangan di daerah. Penelitian ini dilakukan dengan tujuan: 1) perumusan model ekonomi komoditas padi sawah terkait dengan pembiayaan DAK pertanian dan irigasi di Provinsi Jambi; dan 2) analisis dampak pendanaan DAK pertanian dan irigasi terhadap luas areal irigasi, sawah, dan ketahanan pangan di Provinsi Jambi. Hasil simulasi menunjukkan peningkatan dana alokasi khusus (pertanian dan irigasi) memberikan dampak positif terhadap peningkatan areal sawah irigasi, produksi dan ketahanan pangan daerah. Perbaikan efektifitas dan dampak dari alokasi dana DAK disarankan disinergikan dengan alokasi subsidi pupuk dan benih di setiap kabupaten/kota. Fokus alokasi dana DAK bukan hanya sebatas pemeliharaan dan perbaikan jaringan irigasi, tetapi diperluas untuk mengembangkan model irigasi skala kecil pada lahan sawah potensial (tadah hujan, lebak, pasang surut). Potensi jenis lahan yang tersedia memerlukan kecocokan paket teknologi spesifik lokasi untuk tanaman padi dan pangan lainnya. Begitu juga halnya penggunaan input alternatif yang lebih murah. Reorientasi program yang didanai DAK pertanian/irigasi diperlukan untuk mewujudkan efektivitas dan dampaknya terhadap produksi pangan dan ketahanan pangan di daerah.
\end{abstract}

Kata kunci: Dana Alokasi, Irigasi, Ketahanan Pangan, Model Simultan, Padi

\section{PENDAHULUAN}

Kebijakan pemerintah dalam bidang irigasi berupa pembangunan irigasi baru dan pemeliharaan serta rehabilitasi jaringan irigasi. Sebagian besar anggaran irigasi dalam bentuk DAK irigasi tingkat provinsi dan Kabupaten/kota di provinsi Jambi periode 2014 sampai 2018 diperuntukan bagi kegiatan pemeliharaan dan rehabilitasi jaringan irigasi. Dana irigasi tersebut lebih fokus kepada mempertahankan performa dan kerberfungsian irigasi untuk mendukung ketanahan pangan di daerah. Kewenangan pengelolaan jaringan irigasi berdasarkan Peraturan Pemerintah No. 23 Tahun 2014 tentang Irigasi adalah sebagai berikut: a) Daerah Irigasi (DI) dengan luas kecil dari 1000 hektar menjadi wewenang dan tanggung jawab kabupaten/kota (sistem irigasi primer dan sekunder); b) Daerah Irigasi (DI) dengan luas 1000 - 3000 hektar menjadi wewenang dan tanggung jawab provinsi (sistem irigasi primerdan sekunder); dan c) Daerah Irigasi (DI) dengan luas lebih dari 3000 hektar menjadi wewenang dan tanggung jawab Pemerintah Pusat.

Perpres RI Nomor 123/2016 tentang Petunjuk Teknis Dana Alokasi Khusus Fisik menyatakan ruang lingkup bidang/subbidang DAK Fisik meliputi 3 (tiga) jenis: DAK Fisik Reguler, DAK Fisik Penugasan dan DAK Fisik Afirmasi. DAK Fisik Reguler meliputi bidang pendidikan, kesehatan, perumahan dan permukiman, pertanian, kelautan dan perikanan, sentra industri kecil dan menengah dan pariwisata. DAK Fisik Penugasan meliputi bidang pendidikan sekolah menengah kejuruan, kesehatan rumah sakit rujukan, air minum, sanitasi, jalan, pasar, irigasi dan energi skala kecil. DAK Fisik Afirmasi meliputi perumahan dan permukiman, transportasi dan kesehatan. Pemanfaatan DAK bidang pertanian ditujukan untuk: 1) Mendukung produksi komoditas pertanian strategis; 2) Peningkatan produksi bahan pangan untuk pengamanan kebutuhan pangan nasional; 3) Peningkatan nilai tambah, daya saing dan ekspor komoditas pertanian; dan 4) Meningkatkan kinerja pembangunan pertanian di 
daerah. Ruang lingkup kegiatan yang dibiayai DAK Pertanian adalah: 1) Kegiatan pembangunan dan perbaikan balai diklat pertanian, SMK Pertanian dan penyediaan sarana pendukung pertanian; 2) Kegiatan pembangunan dan perbaikan irigasi air tanah dangkal dan dalam, embung, dam parit, dan pintu air di wilayah Kabupaten/Kota.

Selanjutnya pembiayaan Dana Alokasi Khusus (DAK) fisik bidang irigasi ditujukan untuk mendukung pemenuhan kedaulatan pangan yang pelaksanaannya dilakukan melalui kegiatan pembangunan, peningkatan fungsi atau menambah luas areal layanan dan rehabilitasi pada sistem irigasi yang menjadi kewenangan daerah untuk mencapai sasaran nasional pembangunan irigasi 1 juta hektar dan rehabilitasi irigasi 3 juta hektar serta perlindungan daerah hulu sumber air irigasi. Secara rinci kegiatan DAK fisik bidang irigasi untuk provinsi dan kabupaten/kota meliputi : 1) Kegiatan pembangunan irigasi, merupakan seluruh kegiatan penyediaan irigasi di wilayah tertentu yang belum ada jaringan irigasinya, apabila kondisi jaringan irigasi yang menjadi kewenangan provinsi/ kabupaten/ kota sudah berfungsi dengan baik; 2) Peningkatan irigasi, merupakan kegiatan meningkatkan fungsi dan kondisi jaringan irigasi yang sudah ada atau kegiatan menambah luas areal pelayanan pada jaringan irigasi yang sudah ada dengan mempertimbangkan perubahan kondisi lingkungan daerah irigasi; 3) Kegiatan rehabilitasi, merupakan kegiatan perbaikan jaringan irigasi guna mengembalikan fungsi dan pelayanan irigasi seperti semula; dan 4) Perlindungan daerah hulu sumber air irigasi (Perpres RI Nomor 123/2016).

Lahan sawah berpengairan (termasuk tadah hujan, lebak, pasang surut) di Provinsi Jambi mengalami penurunan sebesar -2,35 persen. Pada tahun 2010 mencapai 112.434 hektar menurun menjadi 96.588 hektar pada tahun 2016 (BPS Jambi, 2019). Dalam periode tersebut luas lahan sawah beririgasi (irigasi teknis, setengah teknis, irigasi sederhana/desa) juga mengalami penurunan dari 34.040 hektar pada tahun 2010 menjadi 33.252 hektar tahun 2016 dengan pertumbuhan -0,38 persen. Stagnannya peningkatan lahan sawah di Provinsi Jambi terkait dengan lambanya pembangunan irigasi terutama pada areal sawah tadah hujan dan pencetakan sawah baru termasuk pengaruh konversi ke perkebunan kelapa sawit. Ancaman paling besar konversi lahan sawah ke perkebunan sawit adalah areal sawah tadah hujan, sawah lebak, dan sawah pasang surut sehingga perkembangan lahan sawah non irigasi mengalami penurunan -3,20 persen periode 2010-2016 (BPS Jambi, 2019).

Pembiayaan Dana Alokasi Khusus (DAK) fisik provinsi dan kabupaten/kota untuk pertanian dan irigasi cukup bervariatif. Umumnya alokasi dana DAK berkisar Rp 60-70 milyar per tahun, namun terjadi penurunan pembiayaan DAK fisik yang hanya Rp 30-40 milyar pada tahun 2016 dan 2018 (Kemenkeu, 2019). Sesuai dengan peruntukannya, pembiayaan DAK fisik pertanian dan irigasi di provinsi Jambi diantaranya untuk meningkatkan kinerja pembangunan pertanian tanaman pangan khususnya padi sawah dalam upaya memperkuat kedaulatan pangan di daerah.

Produksi padi sawah di Provinsi Jambi tumbuh sebesar 4,29 persen dalam periode 2010-2016. Peningkatan produksi padi sawah tersebut di dorong oleh terjadinya pertumbuhan luas panen padi sawah sebesar 1,23 persen periode 2010-2016 dan pertumbuhan produktivitas hasil sebesar 1,35 persen dalam periode yang sama (BPS Jambi, 2019). Selanjutnya dalam periode $2018-2020$ produksi padi setara beras mengalami penurunan sebesar $-8,37$ persen yang sebagian besar berupa sawah irigasi dan non irigasi. Penurunan dalam 3 tahun terakhir ini disebabkan oleh penurunan luas panen, sedangkan produktivitas hasil meningkat dari 42,23 kuintal/hektar pada tahun 2018 menjadi 43,41 kuintal/hektar pada tahun 2020 (BPS, 2021).

Pada periode sebelumnya (2010-2016) terjadi peningkatan luas panen padi sawah dan kemungkinan terkait dengan semakin tingginya intensitas tanam padi sawah di Provinsi Jambi terutama pada areal sawah beririgasi. Dalam periode yang sama juga terjadi perbaikan produktivitas padi sawah. Perbaikan produktivitas hasil tersebut kemungkinan terkait dengan semakin intensifnya penggunaan paket teknologi produksi pada sawah beririgasi sehingga ikut memberikan kondisi tumbuh yang baik bagi tanaman padi serta hasil dari budidaya tanaman padi oleh petani. Evaluasi ketercapaian output dan outcome dari kegiatan yang didukung pembiayaan Dana Alokasi Khusus (DAK) pertanian dan irigasi di Provinsi Jambi perlu dilakukan agar alokasi pembiayaan tersebut efektif sesuai dengan tujuannya. Apakah ada keterkaitan antara kinerja pembangunan pertanian tanaman pangan khususnya padi sawah dengan di Provinsi Jambi dengan alokasi Dana Alokasi Khusus (DAK) pertanian dan irigasi.

Investasi adalah suatu perubahan dalam input tetap (fixed inputs) yang digunakan dalam proses produksi. Dalam pengertian lebih mikro, investasi adalah perubahan dalam stok kapital fisik, yaitu input fisik yang mempunyai umur ekonomi satu tahun atau lebih. Peningkatan investasi (lebih tinggi dari tingkat penyusutan) akan menambah stok pembentukan modal tetap (fixed capital formation) berupa pendirian bangunan/ konstruksi, pembelian barang modal baru dari dalam negeri dan pembelian barang modal baru dan bekas dari luar negeri (BPS, 1997). Peningkatan stok modal pertanian dapat berupa investasi pembukaan lahan baru, bangunan/ konstruksi, irigasi dan pencetakan sawah, alsintan, riset pertanian dan transfer teknologi, dan pelatihan sumberdaya manusia terkait perubahan teknologi. Investasi akan meningkatkan stok kapital yang memperbesar kapasitas produksi untuk meningkatan output. Pada sektor pertanian, stok modal mencakup ternak, bangunan dan alat/ mesin pertanian dan 
infrastruktur, termasuk nilai perbaikannya. Ternak juga dianggap stok modal yang diperoleh untuk pembibitan, menghasilkan susu, dan lainnya. Perbaikan lahan, jaringan dan lahan beririgasi juga termasuk dalam stok modal (BPS, 1997).

Investasi infrastruktur biasanya dilakukan oleh pemerintah, sedangkan di bidang produksi riil dilakukan oleh pelaku usahatermasuk rumah tangga pertanian. Pengeluaran insfrastruktur (pengairan dan jalan pertanian), subsidi input, penelitian dan pengembangan, dan penyuluhan serta sekolah lapang pertanian sebagai pengeluaran pemerintah (public spending) untuk pembangunan pertanian (Worl Bank, 2009). Rumah tangga petani melakukan investasi dalam bentuk pembelian indukan ternak sapi untuk pembibitan, susu dan hewan tarik, perbaikan saluran irigasi, dan alat-alat dan mesin pertanian, pembukaan lahan pertanian dan tanaman menjelang panen pertama merupakan investasi.

Sejumlah studi empiris menunjukkan bahwa rendahnya investasi pertanian di Indonesia baik oleh sektor swasta maupun pemerintah adalah salah satu faktor penting yang menyebabkan stagnasi produktivitas dan pertumbuhan pertanian. Hadi, et. al. (2010) melaporkan bahwa investasi pertanian memiliki dampak positif pada PDB sektor pertanian dan penyerapan tenaga kerja baru, dan investasi pertanian oleh petani juga memiliki dampak menguntungkan pada pendapatan. Pengeluaran publik untuk prasarana pertanian khususnya irigasi adalah upaya penting untuk menyediakan sumberdaya pertanian sebagai bagian dari kecukupan lingkungan tumbuh tanaman. Irigasi sebagai aplikasi air buatan untuk tanaman untuk tujuan produksi pangan dan mengatasi kekurangan curah hujan dan membantu menstabilkan produksi pertanian dan produktivitas (FAO, 2012). Pengembangan irigasi disarankan sebagai strategi utama untuk meningkatkan produktivitas pertanian. Akses irigasi adalah salah satu yang diperlukan untuk meningkatkan produktivitas dan pendapatan petani skala kecil (Dereje et.al, 2011).

Ketahanan pangan diartikan sebagai situasi ketika semua orang, setiap saat, memiliki akses fisik dan ekonomi untuk makanan yang cukup, aman dan bergizi yang dibutuhkan untuk mempertahankan kehidupan yang sehat dan aktif (FAO, 2010). Ketahanan pangan memiliki dimensi: 1) Ketersediaan pangan mengacu pada kehadiran fisik makanan dengan jumlah cukup pada rumah tangga atau wilayah; 2) Akses pangan mengacu pada perolehan pangan sesuai gizi dengan sumberdaya yang dimilikinya; 3) Pemanfaatan pangan oleh masyarakat dengan pengetahuan tentang gizi makanan; dan 4) Stabilitas pangan dengan akses yang dibutuhkan dalam jangka pendek dan panjang (Babatunde et al., 2008).Ketahanan pangan rumah tangga atau wilayah menyiratkan bahwa setiap anggota rumah tangga atau anggota masyarakat secara umum memiliki akses ke pangan. Ketahanan pangan oleh kemampuan memproduksi, mengolah, menyimpan, menyiapkan, dan kemampuan daya belinya. Ketahanan pangan juga terkait dengan ketersediaan sumber daya pertanian seperti iklim dan cuaca, jumlah dan kualitas tanah, tingkat dan jenis teknologi, ketersediaan aset produksi serta kapasitas ekonomi dan sosialnya untuk mengakses makanan (Maxwell dan Frankenberg, 1992).

Hubungan antara pertumbuhan output pertanian khususnya disini pertumbuhan output pangan dengan investasi publik pertanian dimulai dari peningkatan pengeluaran pemerintah (government expenditure) sektor pertanian pangan untuk meningkatkan kapasitas, produktivtas dan efisiensi sumberdaya pertanian dalam proses produksi serta tersedianya produksi pangan. Pengeluaran pemerintah tersebut mendorong terjadinya peningkatan stok teknologi, transfer teknologi, adaptasi dalam pemanfaatan teknologi, peningkatan keahlian dan keterampilan sumberdaya manusia, dan perbaikan kualitas input, proses serta hasil pertanian. Dampak keseluruhan dari investasi publik yang biasanya dalam bentuk pengeluaran pemerintah lokal (local government expenditure) adalah terwujudnya peningkatan produksi, produktivitas, dan mutu hasil-hasil pertanian. Keterkaitan dampak pengeluaran pemerintah lokal tersebut untuk sektor pertanian dengan produksi, produktivitas, intensitas penggunaan sumberdaya, dan ketahanan pangan dijelaskan pada Gambar 1.

Hubungan antara kurva pengeluaran aggregat (AE) pada level pemerintah lokal dengan pasar barang dipengaruhi oleh intervensi pemerintah melalui pengeluarannya yang mempengaruhi perekonomian sektoral atau keseluruhan disebut kebijakan fiskal. Besaran pengaruh kebijakan fiskal terhadap perekonomian sektoral terjadi melalui perubahan pada kurva pengeluaran anggregat (AE). Peningkatan pengeluaran pemerintah lokal pada sektor pertanian mendorong perubahan pada stok kapital (modal) baik dalam bentuk modal fisik maupun dalam bentuk keahlian serta keterampilan petani pada sektor tersebut. Peningkatan stok kapital (modal) digunakan dalam kegiatan produksi sehingga mendorong terjadinya peningkatan output sektoral dan perekonomian lokal. Peningkatan output sektoral (pertanian) disebabkan terjadinya peningkatan penggunaan stok kapital (modal) akibat dari perubahan pengeluaran pemerintah lokal. Peningkatan pengeluaran pemerintah lokal pada sektor pertanian menyebabkan terjadinya peningkatan stok kapital (modal) fisik dan perbaikan kapasitas sumberdaya manusia dalam perbaikan dan pengusaian teknologi pertanian, serta semakin efektifnya transfer teknologi melalui berbagai program penyuluhan serta sekolah lapang bagi petani. Berbagai program penyuluhan pertanian dan pendidikan dan pelatihan lapang bagi petani memberikan rekomendasi dan anjuran pemanfaatan paket teknologi pertanian. Peningkatan pengeluaran pemerintah lokal juga semakin mendorong transfer teknologi melalui 
penyuluhan serta sekolah lapang bagi petani. Penyuluhan pertanian dan pendidikan/pelatihan lapang bagi petani memberikan konten tentang rekomendasi dan anjuran pemanfaatan paket teknologi pertanian. Peningkatan pengeluaran pemerintah lokal mendorong terjadinya penguatan stok pengetahuan dan penguasaian teknologi untuk perbaikan produktivitas penggunaan input-input dalam kegiatan produksi pada tingkat usahatani.

Perubahan pengeluaran pemerintah lokal pada sektor irigasi mendorong terpeliharanya infrastruktur irigasi dan jaringannya, mendorong pencetakan/ rehabilitasi sawah sebagai program komplemen, perbaikan manajemen pemakaian air, dan ketersediaan dan akses air sawah bagi petani. Pengeluaran pemerintah lokal memberikan $\mathrm{AE}$

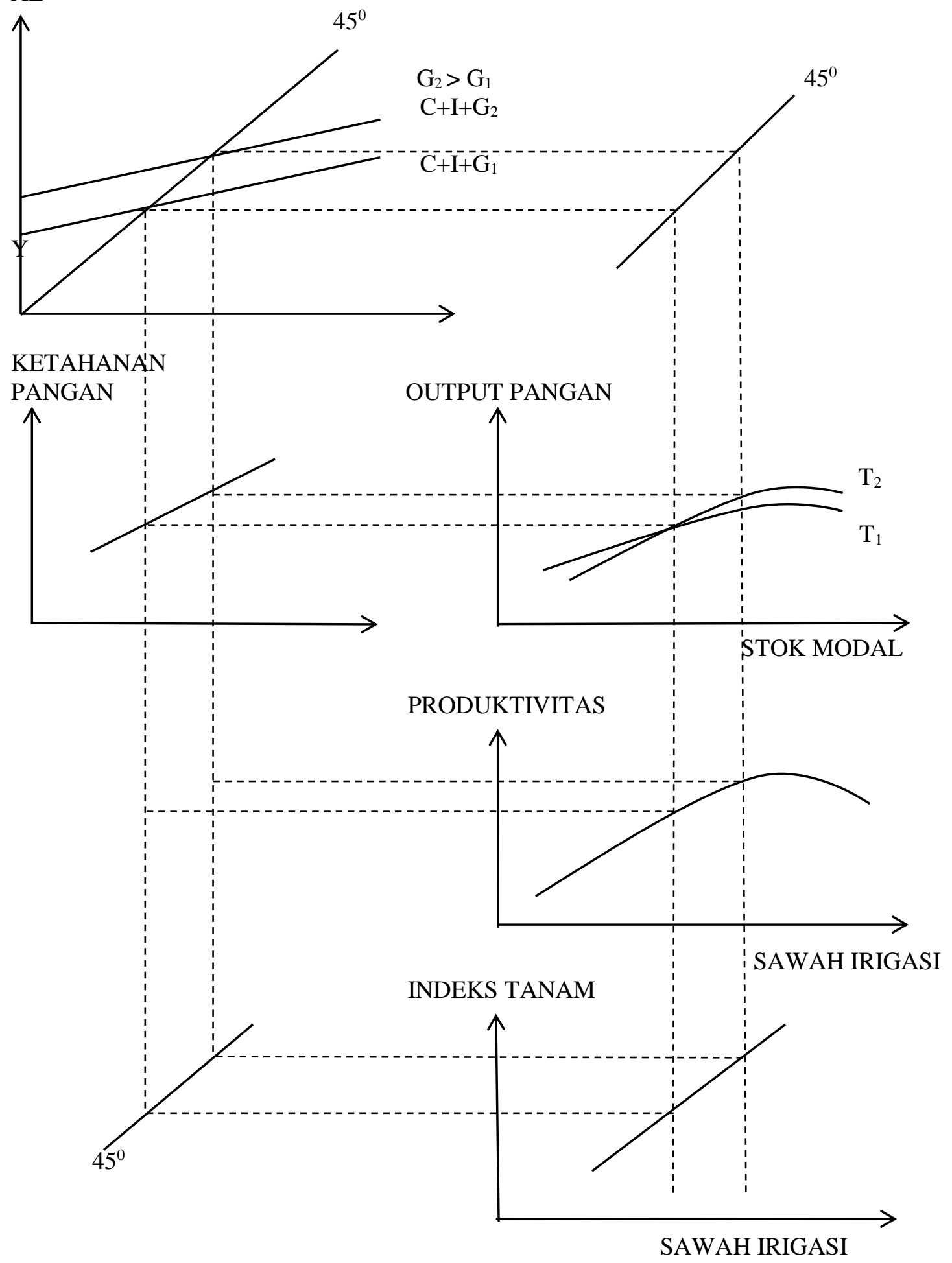

Gambar 1. Keterkaitan antara pengeluaran pemerintah (pertanian dan irigasi) dengan produksi dan ketahanan pangan. 
Dampak terwujudnya stabilitas areal sawah beririgasi dan berpeluang penambahan areal sawah baru melalui program komplemen di tingkat lokal. Penambahan areal sawah beririgasi mendorong peningkatan indeks tanam padi melalui pengurangan variabel pembatas dalam produksi padi dan tanaman pangan lainnya.

Dorongan pengeluaran pemerintah daerah pada sektor pertanian dan irigasi memungkinkan memberikan dampak terhadap peningkatan ketahanan pangan di daerah (local food security) melalui perbaikan kemampuan petani lokal menghasilkan pangan sehingga terhindar dari setuasi kekurangan bahan pangan dan perbaikan aksesnya bagi masyarakat lokal. Tujuan penulisan artikel ilmiah ini secara khusus adalah menganalisis dampak pembiayaan Dana Alokasi Khusus (DAK) pertanian dan irigasi terhadap luas sawah irigasi, intensitas tanam, luas panen, produktivitas hasil, produksi padi sawah dan ketahanan pangan wilayah di Provinsi Jambi. Berkaitan dengan konteks masalah yang telah dipaparkan dari latar belakang, maka dapat dirumuskan permasalahan dalam penelitian ini adalah bagaimana dampak alokasi dana khusus khususnya pertanian dan irigasi terhadap luas areal irigasi, produktivitas dan produksi padi sawah, serta ketahanan pangan pada kabupaten/ kota di provinsi Jambi.

\section{Pengumpulan dan Pengukuran Data}

\section{METODE PENELITIAN}

Dalam penelitian ini semuanya menggunakan data seri waktu tahunan (times series) periode 2014 sampai 2017 untuk semua variabel. Semua data dilakukan disaggregasi menurut 11 (sebelas) kabupaten/kota di Provinsi Jambi. Sumber data berasal dari Biro Pusat Statistik Provinsi Jambi dan kabupaten/kota melalui berbagai jenis publikasi. Data Dana Alokasi Khusus (DAK) Pertanian dan Irigasi berasal dari Direktorat Jenderal Perimbangan Keuangan Kementerian Keuangan RI. Data ketahanan pangan wilayah kabupaten/kota di provinsi Jambi diukur dengan menggunakan konsep yang dipakai oleh Sumarwan dan Sukandar (1998), yang mengukur ketahanan pangan wilayah yaitu ketahanan pangan kabupaten di seluruh Indonesia yang diukur dari kemampuan wilayah untuk memproduksi empat jenis pangan (padi, jagung, ubikayu, ubijalar). Selain itu juga digunakan peubah jumlah penduduk, curah hujan dan Produk Domestik Regional/Bruto (PDRB) sebagaimana berikut ini :

Ketahanan Pangan ${ }_{t}=0,089+2,72 \times 10^{-6} * X 1_{t}-2,25 \times 10^{-8} * X 2_{t}+2,3055^{*} X 3_{t}+2,8542 * X 4_{t}+0,9966 * X 5_{t}+1,1032 * X 6_{t}$

Dimana X1 adalah curah hujan bulan Februari (mm) per tahun, X2 adalah PDRB per kapita (juta Rp), X3 adalah produksi gabah (ton per kapita), X4 adalah produksi jagung (ton per kapita), X5 adalah produksi ubi kayu (ton per kapita), dan X6 adalah produksi ubi jalar (ton per kapita). Persamaan diatas digunakan untuk mengukur indeks ketahanan pangan secara makro yaitu masing-masing wilayah kabupaten/kota dalam Provinsi Jambi mulai tahun tahun 2014 sampai dengan 2017.

\section{Formulasi Model}

Keterkaitan perilaku peningkatan lahan sawah, indeks penanaman padi sawah, luas panen padi sawah, produktivitas hasil, dan ketahanan pangan wilayah dibangun menggunakan model sistem persamaan simultan. Model sistem persamaan telah banyak digunakan oleh peneliti lain terdahulu. Model sistem persamaan simultan yang dibangun terdiri dari 8 (delapan) persamaan struktural sebagai variabel endogen dan 9 (sembilan) variabel eksogen seperti berikut :

Persamaan Struktural:

wahgasi $=\mathrm{A} 0+\mathrm{A} 1 *$ dakgasi $+\mathrm{A} 2 *$ tren;

lahanwah $=\mathrm{B} 0+\mathrm{B} 1 *$ Dwahgasi $+\mathrm{B} 2 *$ Dwahhujan $+\mathrm{B} 3 *$ Drasioput $+\mathrm{B} 4 * \mathrm{Dch}$;

ipwahgasi $=\mathrm{C} 0+\mathrm{C} 1 *$ wahgasi $+\mathrm{C} 2 * \mathrm{Dch}$;

ipsawah $=\mathrm{D} 0+\mathrm{D} 1 *$ ipwahgasi $+\mathrm{D} 2 * \mathrm{ch}$;

luasnen $=\mathrm{E} 0+\mathrm{E} 1 *$ Lhetpuk $+\mathrm{E} 2 *$ Lipsawah $+\mathrm{E} 3 *$ Lipwahlebak $+\mathrm{E} 4 *$ gglnen $+\mathrm{E} 5 *$ tren;

produktiv $=\mathrm{F} 0+\mathrm{F} 1 *$ ipsawah $+\mathrm{F} 2 *$ Dhetpuk $+\mathrm{F} 3 *$ Dprodwah;

prodwah $=\mathrm{G} 0+\mathrm{G} 1 *$ luasnen $+\mathrm{G} 2 *$ produktiv $+\mathrm{G} 3 *$ pgkg 2 ;

kpangan $=\mathrm{H} 0+\mathrm{H} 1 *$ Dpgkg2 $+\mathrm{H} 2 *$ ipsawah $+\mathrm{H} 3 *$ Dprodwah $+\mathrm{H} 4 *$ Lkpangan;

\section{Keterangan:}

lahanwah

wahgasi

ipsawah

ipwahgasi

luasnen

: lahan sawah (irigasi + non irigasi) dalam hektar.

: lahan sawah irigasi dalam hektar.

: indeks tanam sawah (\%).

: indeks tanam sawah irigasi (\%).

: luas panen padi sawah ( hektar). 


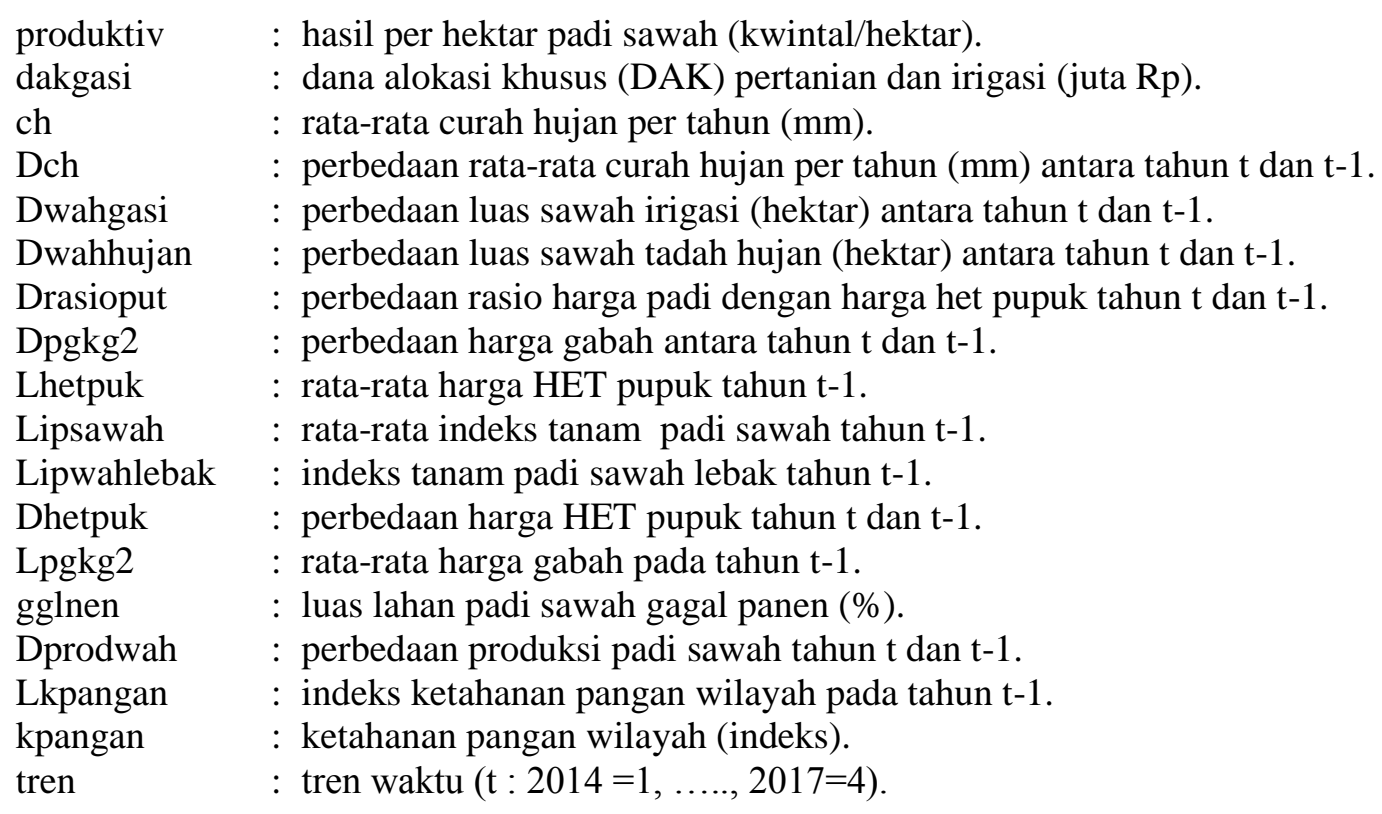

\section{Identifikasi, Estimasi dan Simulasi Model}

Berdasarkan order condition sebagaimana Koutsoyiannis (1977) bahwa persamaan struktural dapat diidentifikasi jika memenuhi kriteria: $(\mathrm{K}-\mathrm{M})=(\mathrm{G}-1)$ disebut exactly identified, $(\mathrm{K}-\mathrm{M})>(\mathrm{G}-1)$ disebut over identified, $(\mathrm{K}-\mathrm{M})<(\mathrm{G}-1)$ disebut unidentified. $\mathrm{G}$ adalah jumlah persamaan (current endogenous variables) dalam model; $\mathrm{M}$ adalah jumlah variabel (endogenous dan exogenous variables) dalam suatu persamaan; dan $\mathrm{K}$ adalah total variabel current endogenous and predetermined. Hasil identifikasi pada setiap persamaan struktural dalam model sistem persamaan diatas semuanya teridentifikasi berlebih sebagaimana pada Tabel 1. Koutsoyiannis (1977) menyatakan model yang teridentifikasi berlebih teridentifikasi berlebih (over identified) disarankan menggunakan metode yang lebih sesuai seperti LIML (Limited Information Likelihood), FIML (Full Information Maximum Likelihood), 2SLS (Two Stage Least Squares) atau 3SLS (Three Stage Least Squares). Secara umum metode kuadrat terkecil tiga tahap (3SLS) menghasilkan estimasi koefisien yang lebih efisien secara asimtotik dibandingkan metode 2SLS. Namun metode 3SLS lebih sensitif terhadap perubahan spesifikasi model yang mempengaruhi semua hasil dugaan koefisien, serta memerlukan data lebih banyak karena semua koefisien diduga secara bersamaan.

Tabel 1. Hasil Identifikasi Model Sistem Persamaan Simultan

\begin{tabular}{lcccc}
\hline \multicolumn{1}{c}{ Persamaan Struktural } & $(\mathbf{G})$ & $(\mathbf{M})$ & $(\mathbf{K})$ & $\begin{array}{c}\text { Identifikasi } \\
(\mathbf{K}-\mathbf{M}) \geq=\leq(\mathbf{G}-\mathbf{1})\end{array}$ \\
\hline Lahan sawah irigasi & 8 & 3 & 17 & over identified \\
over identified \\
Lahan sawah & 8 & 5 & 17 & over identified \\
Indeks tanam padi sawah irigasi & 8 & 3 & 17 & over identified \\
Indeks tanam padi sawah & 8 & 3 & 17 & over identified \\
Luas panen padi sawah & 8 & 6 & 17 & over identified \\
Produktivitas padi sawah & 8 & 4 & 17 & over identified \\
produksi padi sawah & 8 & 4 & 17 & 17 \\
Ketahanan pangan wilayah & 8 & 5 & & \\
\hline
\end{tabular}

Sumber: Model penelitian (2020)

Untuk mengetahui suatu model cukup valid untuk suatu simulasi diperlukan validasi model dengan tujuan untuk menganalisis sejauhmana kemampuan dan keandalan model yang digunakan dapat mendekati data aktual. Validasi model menggunakan Theil's Inequality Coefficients (U) dan Error Correlation Matrix antar persamaan struktural.Tujuan dari simulasi dalam penelitian ini adalah untuk menjelaskan dampak perubahan dari Dana Alokasi Khusus (DAK) pertanian dan irigasi terhadap indeks penanaman, produktivitas hasil padi sawah, dan ketahanan pangan wilayah di provinsi Jambi. Simulasi ini menggunakan simulasi historis (ex-post simulation) periode data tahun 2014 sampai 2017 dengan skenario peningkatan Dana Alokasi Khusus (DAK) pertanian dan irigasi sebesar 10 persen, 20 persen dan 35 persen. 
Zainuddin. Dampak Dana Alokasi Khusus (DAK) Pertanian dan Irigasi Terhadap Produksi Padi Sawah dan Ketahanan Pangan Kabupaten/Kota di Provinsi Jambi

\section{Uji Stasioner Data}

\section{HASIL PENELITIAN}

Panel Unit Roots Test dimaksudkan untuk menguji stasioneritas data setiap variabel. Data panel yang tidak stasioner dapat menyebabkan regresi palsu di mana nilai R-kuadrat terlalu tinggi tetapi variabel tidak signifikan. Jika unit roots terdapat pada suatu rangkaian data pada level, kemudian serangkaian data tersebut pada first defference berubah menjadi stasioner. Jika data stasioner pada level dilambangkan sebagai I (0) atau hanya stasioner setelah perbedaan pertama (first defference) dilambangkan sebagai I (1). Hasil uji panel unit roots dalam penelitian ini dilakukan sebagaimana Levin et al. (2002) dan Breitung (2000) seperti disajikan dalam Tabel 2. Uji panel unit roots untuk semua seri data menunjukkan data stasioner pada level, kecuali uji Breitung menunjukkan data indeks tanam sawah irigasi (ipwahgasi) dan produktivitas hasil padi sawah (produktiv) tidak stasioner pada level, namun dalam pengujian Levin et al. (2002) semua seri data sudah stasioner pada level I(0).

Table 2. Hasil Uji Panel Unit Roots

\begin{tabular}{|c|c|c|c|c|}
\hline \multirow[t]{2}{*}{ Variabel } & \multicolumn{2}{|c|}{ Levin, Lin \& Chu } & \multicolumn{2}{|c|}{ Breitung } \\
\hline & Level & $1^{\text {st }}$ diff & Level & $1^{\text {st }}$ diff \\
\hline \multicolumn{5}{|l|}{ Variabel endogen } \\
\hline wahgasi & $-5,5189 * * *$ & $-27,8124 * * *$ & $-3,9530 * * *$ & $-1,9353 * *$ \\
\hline lahanwah & $-7,3166 * * *$ & $-7,1422 * * *$ & $-3,9189 * * *$ & $-0,0397$ \\
\hline ipwahgasi & $-3,9091 * * *$ & $-5,5835 * * *$ & $-0,9301$ & $-4,3964 * * *$ \\
\hline ipsawah & $-7,3612 * * *$ & $-9,6688 * * *$ & $-2,5749 * * *$ & $-3,5645 * * *$ \\
\hline luasnen & $-6,6059 * * *$ & $-14,6413 * * *$ & $-4,1394 * * *$ & $-0,6305$ \\
\hline produktiv & $-3,1778 * * *$ & $-6,7852 * * *$ & $-1,2128$ & $-1,3564 *$ \\
\hline prodwah & $-7,4923 * * *$ & $-18,1534 * * *$ & $-4,0717 * * *$ & $-1,0768$ \\
\hline kpangan & $-4,2402 * * *$ & $-8,1652 * * *$ & $-3,0290 * * *$ & $-1,2144$ \\
\hline \multicolumn{5}{|l|}{ Variabel eksogen } \\
\hline dakgasi & $-6,7530 * * *$ & $-4,8211 * * *$ & $-3,1795 * * *$ & $-1,7250 * *$ \\
\hline hetpuk & $-6,6368 * * *$ & $-8,1801 * * *$ & $-5,5867 * * *$ & $-6,1232 * * *$ \\
\hline ipwahlebak & $-7,8496 * * *$ & $-5,5018 * * *$ & $-6,8588 * * *$ & $-3,1230 * * *$ \\
\hline wahhujan & $-7,8496 * * *$ & $-5,5018 * * *$ & $-6,8588 * * *$ & $-3,1230 * * *$ \\
\hline rasioput & $-6,1199 * * *$ & $-6,9779 * * *$ & $-2,7104 * *$ & $-0,6588$ \\
\hline pgkg2 & $-7,7381 * * *$ & $-1,3547 *$ & $-2,3551 * * *$ & $-1,2266$ \\
\hline gglnen & $-5,1192 * * *$ & $-5,9400 * * *$ & $-2,7779 * * *$ & $-3,5086 * * *$ \\
\hline $\mathrm{ch}$ & $-5,3625 * * *$ & $-9,5036 * * *$ & $-2,6935 * * *$ & $-2,5500 * * *$ \\
\hline
\end{tabular}

Sumber : Data olahan penelitian (2020)

Keterangan: $* * * * * *$ adalah siginifikan secara statistik taraf $1 \%, 5 \%$ dan $10 \%$

Table 3. Matrik Korelasi Error Terms Antar Persamaan Struktural Dalam Model

\begin{tabular}{|c|c|c|c|c|c|c|c|c|}
\hline \multicolumn{9}{|c|}{ Cross Model Correlation } \\
\hline & wahgasi & lahanwah & ipwahgasi & ipsawah & luasnen & produktiv & prodwah & kpangan \\
\hline wahgasi & 1,00000 & 0,15532 & $-0,24789$ & 0,01851 & 0,31914 & $-0,01516$ & 0,44852 & $-0,06483$ \\
\hline lahanwah & 0,15532 & 1,00000 & $-0,32669$ & $-0,15427$ & 0,46848 & $-0,21432$ & $-0,05230$ & 0,19816 \\
\hline ipwahgasi & $-0,24789$ & $-0,32669$ & 1,00000 & $-0,19791$ & $-0,03146$ & $-0,06210$ & 0,08491 & $-0,16222$ \\
\hline ipsawah & 0,01851 & $-0,15427$ & $-0,19791$ & 1,00000 & 0,16157 & $-0,14282$ & 0,01501 & $-0,05342$ \\
\hline luasnen & 0,31914 & 0,46848 & $-0,03146$ & 0,16157 & 1,00000 & $-0,01846$ & 0,03279 & 0,20337 \\
\hline produktiv & $-0,01516$ & $-0,21432$ & $-0,06210$ & $-0,14282$ & $-0,01846$ & 1,00000 & $-0,25466$ & 0,46592 \\
\hline prodwah & 0,44852 & $-0,05230$ & 0,08491 & 0,01501 & 0,03279 & $-0,25466$ & 1,00000 & $-0,15308$ \\
\hline kpangan & $-0,06483$ & 0,19816 & $-0,16222$ & $-0,05342$ & 0,20337 & 0,46592 & $-0,15308$ & 1,00000 \\
\hline
\end{tabular}

Sumber : Data olahan penelitian (2020)

Table 4. Validasi Model Persamaan

\begin{tabular}{lrrrr}
\multicolumn{1}{c}{ Variabel Endogen } & \multirow{2}{*}{ Satuan } & \multicolumn{2}{c}{ Nilai } & \multicolumn{2}{c}{$\begin{array}{c}\text { Statistik } \\
\text { U-Theil }\end{array}$} \\
\cline { 3 - 4 } & & Aktual & \multicolumn{1}{c}{ Prediksi } \\
\hline Lahan sawah irigasi & Hektar & 4351,60 & 4351,60 & 0,31 \\
Lahan sawah & Hektar & 8639,20 & 8639,20 & 0,24 \\
Indeks tanam sawah irigasi & Persen & 128,30 & 128,30 & 0,27 \\
Indeks tanam sawah & Persen & 122,70 & 122,70 & 0,17 \\
Luas panen padi sawah & Hektar & 10828,80 & 10834,50 & 0,24
\end{tabular}


Zainuddin. Dampak Dana Alokasi Khusus (DAK) Pertanian dan Irigasi Terhadap Produksi Padi Sawah dan Ketahanan Pangan Kabupaten/Kota di Provinsi Jambi

\begin{tabular}{lcrrr} 
Produktivitas padi sawah & Kw/Hektar & $48, .20$ & 48,20 & 0,10 \\
Produksi padi sawah & Ton & 52214,10 & 52238,30 & 0,26 \\
Ketahanan pangan wilayah & Indeks & 0,78 & 0,77 & 0,20 \\
\hline
\end{tabular}

Sumber : Data olahan penelitian (2020)

\section{Hasil Estimasi dan Validasi Model}

Model sistem persamaan simultan yang mengkaitkan perilaku peningkatan lahan sawah, indeks penanaman padi sawah, luas panen padi sawah, produktivitas hasil, dan ketahanan pangan wilayah di provinsi Jambi diestimasi dengan metode 3SLS (Three Stage Least Squares Method) melalui penggunaan software SAS/ETS. Hasil estimasi model sistem persamaan disajikan pada Tabel 5.

Table 5. Hasil Estimasi Sistem Persamaan Simultan Dengan Metode 3SLS

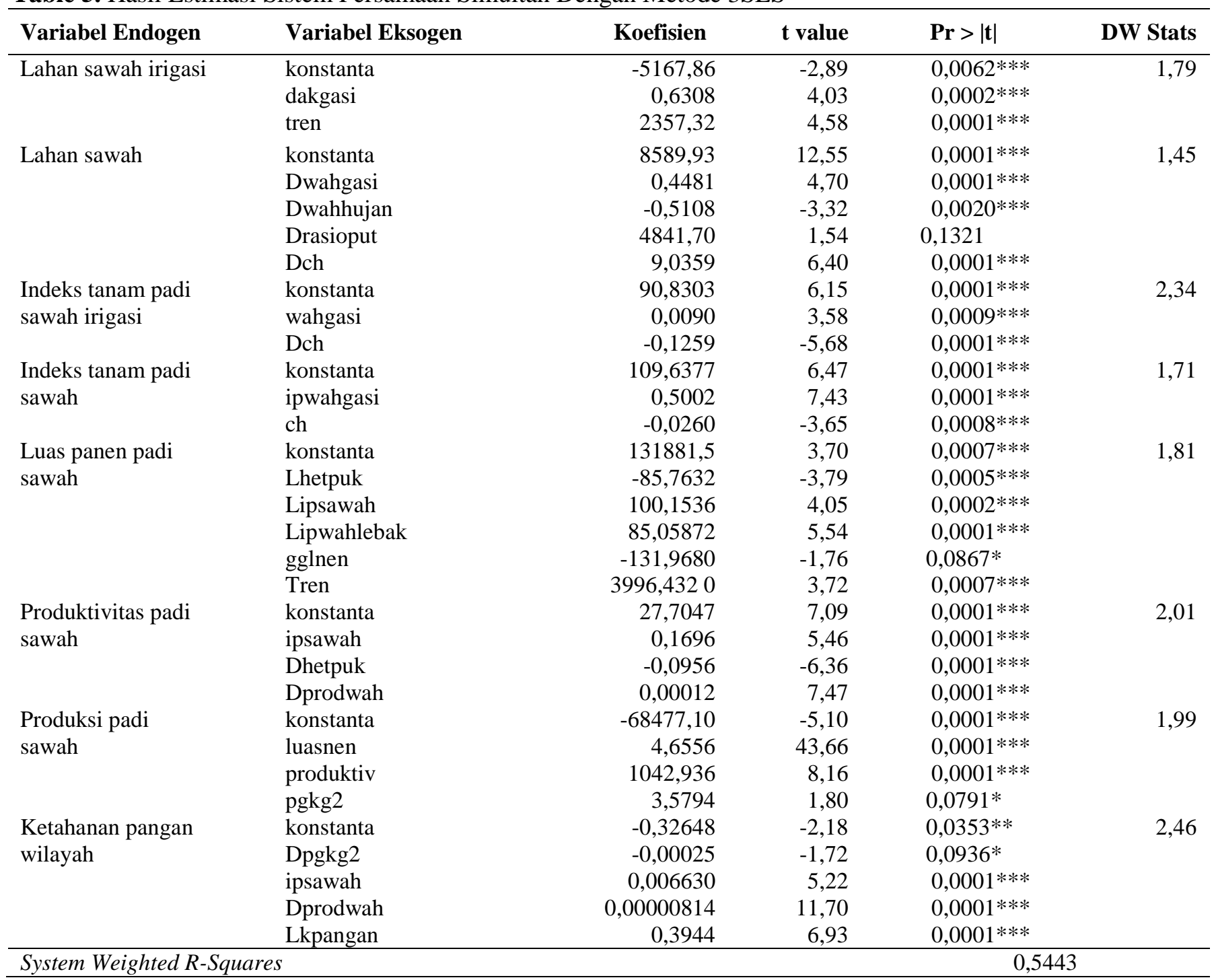

Sumber : Data olahan penelitian (2020)

Keterangan: $* * * * * *$ adalah siginifikan secara statistik taraf $1 \%, 5 \%$ dan $10 \%$.

Spesifikasi model menunjukkan relatif sesuai dengan data aktual dimana R-Squares sistem (System Weighted R-Squares) mencapai sebesar 54.43 persen. Hampir seluruh variabel penjelas (exogenous variables) dalam setiap persamaan struktural adalah signifikan secara statistik sampai dengan 1 persen, kecuali variabel Drasioput (perbedaan rasio harga padi dengan harga het pupuk antar tahun berurutan) siginifikan lebih dari 10 persen pada persamaan lahan sawah (lahanwah). Kemudian beberapa variabel hanya siginifikan sampai 10 persen yaitu variabel gglnen (gagal panen) pada persamaan luas panen padi sawah, variabel pgkg2 (harga gabah) pada persamaan produksi padi sawah, dan variabel Dpgkg2 (perbedaan harga gabah antar tahun berurutan) pada 
persamaan ketahan pangan. Secara umum hasil estimasi model relatif baik. Kemudian tanda (sign) koefisien sesuai dengan teori ekonomi.

Masalah timbulnya autokorelasi antar pengamatan pada setiap persamaan struktural menunjukkan relatif lemah sebagaimana statistik Durbin-Watson berkisar antara 1,45 sampai 2,46 atau tidak terlalu besar menyimpang dari angka 2. Kesesuaian model juga dilihat dari korelasi antar error terms diantara persamaan struktural dalam model. Berdasarkan Tabel 3 menunjukkan korelasi error terms antara persamaan struktural relatif lemah. Koefisien korelasi sama atau lebih kecil dari 0,30 mencapai 87 persen dan antara 0,31 sampai 0,39 mencapai 13 persen. Jadi disimpulkan hasil estimasi koefisien dalam model sistem persamaan tersebut dianggap tidak bias dan efisien secara asimtotik.

Untuk mengetahui apakah model cukup valid untuk membuat suatu simulasi kebijakan maka perlu dilakukan suatu validasi model dengan tujuan untuk menganalisis sejauhmana model tersebut dapat mewakili dunia nyata (Pindyck and Rubinfield 1991). Kriteria statistik untuk validasi model ekonometrika yang digunakan dalam penelitian ini adalah Theil's Inequality Coefficient (U). Kriteria penilaian model yang baik adalah model yang menghasilkan nilai $U$ Theil yang relatif kecil. Nilai koefisien U-Theil (U) berkisar antara 0 dan 1. Jika U semakin mendekati nilai 0 maka model semakin baik. Validasi model dilakukan pada periode tahun $2014-2017$.

Statistik U-Theil dalam Tabel 4 menunjukkan bahwa semua persamaan mempunyai nilai U-Theil dibawah 0,3 kecuali satu persamaan struktural lahan sawah irigasi dengan U-Theil sebesar 0,31. Angka statistik tersebut menunjukkan model relatif cukup baik untuk simulasi dampak dari Dana Alokasi Khusus (DAK) pertanian dan irigasi pada kabupaten/kota di provinsi Jambi yang menjadi perhatian penting dari penelitian ini.

\section{Analisis Dampak Dana Alokasi Khusus (DAK) Pertanian dan Irigasi}

Model sistem persamaan simultan diatas selanjutnya digunakan untuk melakukan simulasi dampak Dana Alokasi Khusus (DAK) sektor pertanian dan irigasi pada 11 kabupaten/kota di provinsi Jambi dalam periode 2014 sampai dengan 2017 dengan skenario simulasi berikut ini:

1) Dampak peningkatan alokasi Dana Alokasi Khusus (DAK) di kabupaten/kotasebesar 10 persen terhadap luas lahan irigasi, indeks tanam padi sawah, produktivitas hasil padi sawah, produksi padi sawah, dan ketahanan pangan wilayah.

2) Dampak peningkatan alokasi Dana Alokasi Khusus (DAK) di kabupaten/kota sebesar 20 persen terhadap luas lahan irigasi, indeks tanam padi sawah, produktivitas hasil padi sawah, produksi padi sawah, dan ketahanan pangan wilayah.

3) Dampak peningkatan alokasi Dana Alokasi Khusus (DAK) di kabupaten/kota sebesar 35 persen terhadap luas lahan irigasi, indeks tanam padi sawah, produktivitas hasil padi sawah, produksi padi sawah, dan ketahanan pangan wilayah.

Hasil simulasi peningkatan Dana Alokasi Khusus (DAK) pada kabupaten/kota di Provinsi Jambi secara umum memberikan dampak positif terhadap luas lahan irigasi, indeks tanam padi sawah, produktivitas hasil padi sawah, produksi padi sawah, dan ketahanan pangan wilayah sebagaimana Tabel 6.

Table 6. Dampak DAK Pertanian dan Irigasi Terhadap Padi Sawah dan Ketahanan Pangan Kabupaten/Kota di Provinsi Jambi

\begin{tabular}{|c|c|c|c|c|c|}
\hline \multirow[t]{3}{*}{ Variabel Endogen } & \multirow[t]{3}{*}{ Satuan } & \multirow{3}{*}{$\begin{array}{c}\text { Nilai } \\
\text { Dasar } \\
\text { Simulasi }\end{array}$} & \multirow{2}{*}{\multicolumn{3}{|c|}{$\begin{array}{c}\text { Perubahan (persen) } \\
\text { Peningkatan DAK Pertanian dan } \\
\text { Irigasi }\end{array}$}} \\
\hline & & & & & \\
\hline & & & $10 \%$ & $20 \%$ & $35 \%$ \\
\hline Lahan sawah irigasi & hektar & 4351,60 & 7,89 & 15,78 & 27,62 \\
\hline Lahan sawah & hektar & 8639,20 & 0,64 & 0,69 & 0,76 \\
\hline Indeks tanam sawah irigasi & persen & 128,30 & 2,42 & 4,83 & 8,50 \\
\hline Indeks tanam sawah & persen & 122,70 & 1,22 & 2,53 & 4,40 \\
\hline Luas panen padi sawah & hektar & 10834,50 & 1,40 & 2,79 & 4,89 \\
\hline Produktivitas padi sawah & kw/hektar & 48,20 & 0,58 & 1,13 & 1,95 \\
\hline Produksi padi sawah & ton & 52238,30 & 1,90 & 3,78 & 6,59 \\
\hline Ketahanan pangan wilayah & indeks & 0,77 & 2,91 & 5,10 & 8,39 \\
\hline
\end{tabular}

Sumber : Data olahan penelitian (2020)

Peningkatan Dana Alokasi Khusus (DAK) untuk sektor pertanian dan irigasi pada kabupaten/kota pada kondisi kenaikan anggaran yang lemah (weak condition) sebesar 10 persen, memberikan dampak peningkatan luas 
lahan sawah beririgasi sebesar 7,89 persen. Kenaikan lahan sawah beririgasi tersebut mendorong peningkatan indeks tanam 2,42 persen untuk sawah irigasi dan 1,22 persen untuk sawah keseluruhan. Peningkatan indeks tanam dan lahan sawah irigasi memberikan dampak kenaikan luas panen padi sawah sebesar 1,40 persen. Dana Alokasi Khusus (DAK) sektor pertanian dan irigasi pada kabupaten/kota juga mempengaruhi produktivitas hasil padi sawah. Peningkatan DAK pertanian dan irigasi tersebut juga memberikan dampak terjadinya kenaikan produktivitas hasil padi sawah sebesar 0,58 persen. Kenaikan luas panen dan produktivitas padi sawah memberikan dampak lanjutan terhadap peningkatan produksi padi sawah sebesar 1,90 persen pada level kabupaten/kota. Hasil simulasi ini selain mampu meningkatkan produksi padi sawah, tetapi juga memberikan dampak memperbaiki indeks ketahanan pangan wilayah sebesar 2,91 persen.

Peningkatan Dana Alokasi Khusus (DAK) untuk sektor pertanian dan irigasi pada kabupaten/kota pada kondisi kenaikan anggaran yang moderat (moderate condition) sebesar 20 persen, memberikan dampak peningkatan luas lahan sawah beririgasi sebesar 15,78 persen. Kenaikan lahan sawah beririgasi tersebut mendorong peningkatan indeks tanam 4.83 persen untuk sawah irigasi dan 2,53 persen untuk sawah keseluruhan. Peningkatan indeks tanam dan lahan sawah irigasi memberikan dampak kenaikan luas panen padi sawah sebesar 2,79 persen. Dana Alokasi Khusus (DAK) sektor pertanian dan irigasi pada kabupaten/kota juga mempengaruhi produktivitas hasil padi sawah. Peningkatan DAK pertanian dan irigasi tersebut juga memberikan dampak terjadinya kenaikan produktivitas hasil padi sawah sebesar 1,13 persen. Kenaikan luas panen dan produktivitas padi sawah memberikan dampak lanjutan terhadap peningkatan produksi padi sawah sebesar 3,78 persen pada level kabupaten/kota. Hasil simulasi ini selain mampu meningkatkan produksi padi sawah, tetapi juga memberikan dampak memperbaiki indeks ketahanan pangan wilayah sebesar 5,10 persen.

Peningkatan Dana Alokasi Khusus (DAK) untuk sektor pertanian dan irigasi pada kabupaten/kota pada kondisi kenaikan anggaran yang kuat (strong condition) sebesar 35 persen, memberikan dampak peningkatan luas lahan sawah beririgasi sebesar 27,62 persen. Kenaikan lahan sawah beririgasi tersebut mendorong peningkatan indeks tanam 8,50 persen untuk sawah irigasi dan 4,40 persen untuk sawah keseluruhan. Peningkatan indeks tanam dan lahan sawah irigasi memberikan dampak kenaikan luas panen padi sawah sebesar 4,89 persen. Dana Alokasi Khusus (DAK) sektor pertanian dan irigasi pada kabupaten/kota juga mempengaruhi produktivitas hasil padi sawah. Peningkatan DAK pertanian dan irigasi tersebut juga memberikan dampak terjadinya kenaikan produktivitas hasil padi sawah sebesar 1,95 persen. Kenaikan luas panen dan produktivitas padi sawah memberikan dampak lanjutan terhadap peningkatan produksi padi sawah sebesar 6,59 persen pada level Provinsi Jambi (agregasi kabupaten/kota). Hasil simulasi ini selain mampu meningkatkan produksi padi sawah, tetapi juga memberikan dampak memperbaiki indeks ketahanan pangan wilayah sebesar 8,39 persen.

Secara umum dapat disimpulkan bahwa kebijakan meningkatkan Dana Alokasi Khusus (DAK) pertanian dan irigasi pada anggaran pemerintah kabupaten/kota di Provinsi Jambi merupakan upaya untuk meningkatkan investasi publik pada sektor pertanian dan irigasi. Investasi publik tersebut meningkatkan stok kapital baik berupa kapital fisik dan modal perbaikan sumberdaya manusia bagi aparatur pertanian dan petani. Hasil simulasi menunjukkan semakin meningkatnya stok kapital (modal) mampu memberikan dampak positif terhadap peningkatan sumberdaya, produksi pangan, dan ketahanan pangan wilayah di Provinsi Jambi.

Nadhisa (2018) menunjukkan Dana Alokasi Khusus (DAK) bidang pertanian secara signifikan memiliki pengaruh yang positif terhadap produktivitas usahatani padi di wilayah sentra padi di Indonesia. Hasil penelitian lainnya menunjukkan realisasi Dana Alokasi Khusus (DAK) bidang pertanian berhubungan positif dan signifikan dengan produktivitas padi dan produktivitas jagung di Jawa Timur (Pancarini, 2016). Selanjutnya Nugroho (2017) secara empiris menganalisis dampak langsung dan tidak langsung dari berbagai pengeluaran pembangunan pemerintah di Indonesia untuk meningkatkan produktivitas pertanian dan memerangi kemiskinan dengan cara meningkatkan tingkat upah, menstabilkan harga, dan meningkatkan lapangan kerja non-pertanian menggunakan pendekatan persamaan simultan dan data panel provinsi periode 2005-2014. Hasil penelitiannya menunjukkan pengeluaran pertanian dan pendidikan tidak hanya signifikan mendorong produktivitas, tetapi juga mengurangi kemiskinan. Pengeluaran pemerintah untuk jalan, irigasi, dan listrik terlihat memiliki efek terbatas pada pertumbuhan pertanian dan lemah dampaknya dalam penguarangan kemiskinan. Suwardi (2011) juga dalam penelitiannya yang menyimpulkan bahwa pengeluaran pemerintah daerah (lokal) dalam kegiatan infrastruktur (irigasi dan jalan) mempengaruhi produktivtas pertanian dan jumlah orang miskin di Indonesia.

Apa yang ditemukan dalam penelitian ini di tingkat daerah, sejalan dengan hasil penelitian ADB (2019) yang mengungkap bahwa 22 juta penduduk Indonesia masih menderita kelaparan kronis selama periode 2016-2018 meski sektor pertanian dan ekonomi mencatatkan kemajuan yang cukup signifikan. Dalam publikasi berjudul "Policies to Support Investment Requirements of Indonesia's Food and Agriculture Development During 2020-2045" yang berkerjasama dengan International Food Policy Research Institute (FPRI). Walaupun Indonesia memiliki kemajuan dalam pembangunan pertanian, namun kesenjangan akses pangan masih terjadi di Indonesia. Berdasarkan laporan 
Global Food Security Index (GFSI), pada tahun 2018 Indonesia menempati peringkat ke-68 dari 113 negara. Posisi ini lebih rendah dibandingkan negara-negara Asia Tenggara lainnya seperti Singapura (1), Malaysia (40), Thailand (54), dan Vietnam (62). Posisi yang rendah ini disebabkan tingkat akses makanan yang rendah di Indonesia terutama bagi penduduk miskin dan rentan di perdesaan.

Kerawanan pangan didefinisikan sebagai situasi di mana orang atau individu kurang memiliki akses fisik dan ekonomi ke pangan yang cukup, aman dan bergizi yang dibutuhkan untuk mempertahankan kehidupan yang sehat dan aktif. Lebih lanjut hasil penelitian ADB (2019) juga menyarankan jalan keluar dari masalah ketahanan pangan dan kelaparan adalah serangkaian kebijakan yang harus dilakukan Indonesia mulai dari realokasi subsidi pupuk dan kebijakan peningkatan investasi pemerintah dalam penelitian pertanian, infrastruktur pedesaan, dan irigasi untuk beberapa tahun kedepan hingga 2034. Saran dari ADB tersebut juga perlunya perubahan strategis dalam kebijakan investasi pemerintah, perubahan regulasi dan penyuluhan pertanian untuk meningkatkan kinerja ekonomi Indonesia, selain untuk meningkatkan ketahanan pangan dan menghapus kelaparan. Realokasi subsidi pupuk untuk investasi pertanian, termasuk riset dan pengembangan ( $\mathrm{R} \& \mathrm{D})$ pertanian akan meningkatkan produktivitas pertanian, pembangunan ekonomi nasional (PDB) dan mengurangi kelaparan. Beberapa skenario investasi pertanian bahkan dapat meningkatkan kinerja perekonomian.

Investasi merupakan faktor pembatas bagi kapasitas produksi pertanian karena terjadi suatu perkembangan yang mengkhawatirkan yaitu investasi publik dan swasta di bidang pertanian menurun. Turunnya investasi publik menjadi perhatian besar karena investasi publik pada infrastruktur dasar, pembentukan modal sumberdaya manusia (SDM) dan sumberdaya penelitian dan pengembangan (litbang) merupakan prakondisi yang diperlukan bagi investasi swasta (Evenson dan McKinsey, 1991). Investasi publik juga mendorong berkembangnya adopsi teknologi, menstimulasi investasi komplemen pada produksi pertanian dan penggunaan input, dan pemasaran hasil-hasil pertanian (Nelson, 1981).

Fakta empiris di Afrika dikemukan oleh Jayne et al. (1994) yang menyimpulkan terjadinya penurunan tajam dalam investasi publik dan pertumbuhan di Zimbabwe selama ada komplementaritas kebijakan publik terhadap investasi pada teknologi irigasi dan penggunaan input. Selanjutnya ditemukan bahwa pengeluaran pemerintah di perdesaan 20 negara Amerika Latin mempunyai dampak positif pada pertumbuhan pertanian (Alcott et al. 2006). Fuglie (2004) mengidentifikasi bahwa stagnasi pertumbuhan pertanian di Indonesia sejak awal dekade 1990an disebabkan oleh rendahnya tingkat investasi swasta dan investasi pemerintah. Investasi pemerintah pada penelitian dan pengembangan, infrastruktur perdesaan dan irigasi sangat penting sebagai komplemen bagi investasi swasta di bidang pertanian. Kontribusi penting dampak pengeluaran pemerintah dalam infrastruktur pertanian sesuai dengan hasil analisis World Bank (2009) yang menemukan bahwa pengeluaran pemerintah mempunyai dampak positif terhadap laju pertumbuhan PDB pertanian per kapita. Dalam analisis tersebut, investasi pemerintah mencakup pengeluaran untuk infrastruktur fisik pertanian (irigasi, jalan pertanian), subsidi input, sumberdaya penelitian dan pengembangan (litbang), dan program penyuluhan pertanian untuk melakukan transfer teknologi pertanian (biologis, mekanis, kimiawi, rekayasa sosial) dari sumbernya ke petani.

1. Penelitian ini dapat disimpulkan bahwa kebijakan peningkatan Dana Alokasi Khusus (DAK) pada anggaran pemerintah kabupaten/kota di provinsi Jambi adalah perbaikan investasi publik pada sektor pertanian dan irigasi. Investasi publik meningkatkan stok kapital baik berupa kapital fisik dan modal perbaikan sumberdaya manusia bagi aparatur pertanian dan petani. Hasil simulasi menunjukkan semakin meningkatnya stok kapital (modal) mampu memberikan dampak positif terhadap peningkatan sumberdaya, produksi pangan, dan ketahanan pangan wilayah.

2. Untuk meningkatkan produksi pangan (padi sawah) pada wilayah kabupaten/kota di Provinsi Jambi, salah satunya bisa dilakukan melalui peningkatan anggaran pertanian dan irigasi melalui Dana Alokasi Khusus (DAK) dari pemerintah pusat. Pemerintah daerah kabupaten/kota perlu mereview kembali kebutuhan alokasi pupuk dan bibit bersubsisdi di wilayahnya, apakah besaran alokasinya dinilai efektif meningkatkan produksi pangan teruatama padi sawah. Jika bisa dikurangi kemungkinan lebih berdayaguna untuk meningkatkan anggaran Dana Alokasi Khusus (DAK) terutama untuk percepatan jaringan irigasi dan pencetakan sawah serta perluasan pendidikan dan pelatihan bagi petani. Sumberdaya lahan beririgasi menjadi semakin penting bagi petani tidak hanya terkait peningkatan indeks tanam tetapi juga lebih memungkinkan memperbaiki produktivitas hasil.

3. Ketersediaan lahan basah pada sejumlah kabupaten/kota di Provinsi Jambi masih relatif besar, yaitu berupa lahan sawah tadah hujan, lahan sawah lebak, dan lahan pasang surut. Selama ini sebagian besar penggunaan Dana Alokasi Khusus (DAK) irigasi lebih fokus kepada pemeliharaan dan perbaikan jaringan irigasi yang di sinergikan dengan program pencetakan sawah dan program optimasi lahan pada beberapa kabupaten/kota. Untuk mempercepat peningkatan areal sawah beririgasi di daerah diperlukan perluasan dan penajaman sasaran untuk 
mengembangkan model irigasi skala kecil - menengah untuk pemanfaatan lahan tadah hujan, lebak dan pasang surut agar biasa dimanfaatkan petani lebih produktif untuk tanaman padi dan pangan lainnya.

4. Potensi jenis lahan yang tersedia (tadah hujan, lebak, pasang surut) pada beberapa kabupaten/kota memerlukan kecocokan varietas padi dan pangan lainnya. Begitu juga halnya teknis budidaya dan penggunaan input alternatif yang lebih murah. Untuk mewujudkan hal itu diperlukan reorientasi program yang didanai dengan Dana Alokasi Khusus (DAK) pertanian pada setiap kabupaten/kota di Provinsi Jambi.

\section{DAFTAR PUSTAKA}

Alcott, H., Lederman, D., \& Lopez. R. (2006). Political Institutions, Inequality, and Agricultural Growth: The Public Expenditure Connection. The World Bank Policy Research Working Paper 3902.Washington.

ADB. (2019).Policies to Support Investment Requirements of Indonesia's Food and Agriculture Development During 2020-2045. Mandaluyong City, 1550 Metro Manila, Philippines. Publication : available: http://www.adb.org

BPS. (1997). Estimation of Capital Stock and Investment Matrix in Indonesia. Background Paper. Capital Stock Conference. Jakarta, March, 1997.

BPS. (2019). Pengairan Lahan Sawah (hektar). Tersedia: www.bps.provinsi jambi.go.id

BPS. (2021). Provinsi Jambi Dalam Angka. Tersedia: www.bps.provinsi jambi.go.id

Breitung, J. (2000). The Local Power of Some Unit Root Tests for Panel Data, in: B.Baltagi (ed.), Non stationary Panels, Panel Cointegration, and Dynamic Panels, Advances in Econometrics, Amsterdam, 15, 161-178.

Babatunde, R. O., Omotesho. O. A., Olorunsanya, E. O., \& Owotoki, G. M. (2008). Determinants of Vulnerability to Food Insecurity: A gender-based analysis of farming households in Nigeria. Indian Journal of Agricultural Economics, 63(1),116-125.

Dereje, B., Regassa, N., Ayalneh, B., \& Abonesh. T. (2011). Impact of Small-Scale Irrigation on Household Proverty: Empirical Evidence from the Ambo District in Ethiopia. Irrig. and Drain. 60 (1), 1-10.

Evenson, R.E., \& McKinsey. J. W. (1991). Research, Extension, Infrastructure, and Productivity Change in Indian Agriculture in R.E. Evenson and C.E. Pray (eds). Research and Productivity in Asian Agriculture. Cornell University Press. Ithaca, USA, 158-184.

FAO. (2010).The State of Food Insecurity in the World in Addressing food insecurity in protracted crises. Food and Agriculture Organization of the United Nations, Rome.

FAO. (2012). Irrigation in Southern and Eastern Asia. Food and Agriculture Organization of the United Nations, Rome.

Fuglie, K. O. (2004) Productivity Growth in Indonesian Agriculture, 1961-2000. Bulletin of Indonesian Economic Studies, 40(2), 209-225.

https://doi.org/10.1080/0007491042000205286

Hadi, P. U., Simatupang, P., Situmorang, J., Wahida., Nuryanti, S., \& Purba, H.J. (2010). Analisis Dampak Investasi Pertanian Terhadap Kinerja Sektor Pertanian. Laporan Akhir Penelitian. Pusat Sosial Ekonomi dan Kebijakan Pertanian. Badan Penelitian dan Pengembangan Pertanian. Kementerian Pertanian.

Jayne, T.S., Khatri, Y., C. Thirtle, C., \& Reardon, T. (1994). Determinants of productivity change using a profit function: smallholder agriculture in Zimbabwe. American Journal of Agricultural Economics, 76(3), 613 618.

Koutsoyiannis, A. (1977). Theory of Econometrics. Second Edition. Macmillan Press. United Kingdom.

Levin, A., Lin, C. F., \& Chu, C. S. J. (2002). Unit root tests in panel data: Asymptotic and finite-sample properties. Journal of Econometrics, 108 (1), 1-24.

Maxwell, S., \& Frankenberger. T. (1992). Household Food Security: Concepts, Indicators, Measurements: A technical review. Rome: International Fund for Agricultural Development/United Nations Children's Fund.

Nelson, R. (1981). Research on Productivity Growth and Productivity Differences: Dead Ends and New Departures. Journal of Economic Literature, 19 (3), 1029-1064.

Nugroho, P. E. (2017). Government Expenditure, Agricultural Productivity, and Poverty Reduction in Indonesia: A Simultaneous Equations Approach. Graduate School of Asia-Pacific Studies, Waseda University. Journal of the Graduate School of Asia-Pacific Studies, 34 (9), 39-54.

Nadhisa, M. S. (2018). Dana Alokasi Khusus (DAK) Bidang Pertanian dan Kinerja Usahatani Padi Dalam Mencapai Swasembada Pangan. Institut Pertanian Bogor. Retrieved from http://repository.ipb.ac.id/handle/123456789/96332

Pindyck, R. \& Rubinfeld, D. (1991). Econometric Models and Econometric Forecasts. Mac Graw-Hill, New York. 
Zainuddin. Dampak Dana Alokasi Khusus (DAK) Pertanian dan Irigasi Terhadap Produksi Padi Sawah dan Ketahanan Pangan Kabupaten/Kota di Provinsi Jambi

Pancarini, A. (2016). Dampak Dana Alokasi Khusus (DAK) Bidang Pertanian terhadap Kinerja Pertanian Pangan di Provinsi Jawa Timur. Institut Pertanian Bogor. Retrieved from

http://repository.ipb.ac.id/handle/123456789/83907

Sumarwan, U., \& Sukandar, D. (1998). Identifikasi Indikator dan Variabel serta kelompok Sasaran dan Wilayah Rawan Pangan Nasional. Kerjasama Jurusan Gizi Masyarakat dan Sumberdaya Keluarga Institut Pertanian dengan Unicef dan Biro Perencanaan Departemen Pertanian.

Suwardi, A. (2011). Pengeluaran Pemerintah Daerah, Produktivitas Pertanian, dan Kemiskinan di Indonesia. Jurnal Ekonomi dan Pembangunan Indonesia, 12(1), 39-55. https://doi.org/10.21002/jepi.v12i1.287

World Bank. (2009). Agriculture Public Spending and Growth in Indonesia. Policy Notes. Indonesia Agriculture

Public Expenditure Review, September 2009. Washington. 